\title{
Isolasi dan Pengukuran Aktivitas Enzim Bromelin dari Ekstrak Kasar Batang Nanas (Ananas comosus) Berdasarkan Variasi pH
}

\author{
NURHIDAYAH $^{1}$, MASRIANY ${ }^{1}$, MASHURI MASRI ${ }^{1}$ \\ ${ }^{1}$ Jurusan Biologi, Fakultas Sains dan Teknologi, UIN Alauddin Makassar \\ J1. Sultan Alauddin 36 Samata, Kab. Gowa 92113 \\ email: riany_sains@yahoo.co.id
}

\begin{abstract}
This research aims to determine the highest protein content and the optimum activity of the enzyme bromelain extracted from pineapple stem. This research was conducted at the Laboratory of Microbiology Makassar Alauddin State Islamic University in May 2013. Variable in this study was the isolation and measurement of bromelain enzyme activity as the independent variable while the crude extract of pineapple stem by variations in $\mathrm{pH}$ as the dependent variable. The type of this research was experiments with bradford method for determination of protein content enzyme bromelain, with ammonium sulfate concentration variation for precipitation was $10-60 \%$, as well as the determination of the enzyme bromelain activity at variation $\mathrm{pH}$ was $4.0 ; 5.0,6.0 ; 7.0$ and 8.0, at $65^{\circ} \mathrm{C}$ temperature with incubation time was 10 minutes. Each stage has done three times in repetition and analyzed spectrometry. The results showed the highest levels of protein precipitation with ammonium sulfate at $60 \%$ was $37,785 \mathrm{mg} / \mathrm{ml}$. While the optimum $\mathrm{pH}$ of the enzyme bromelain activity at $\mathrm{pH} 6.0$ was 1.021 activity units /gram.
\end{abstract}

Keywords: bromelain enzyme, Pineapple stem (Ananas comosus), precipitation with ammonium sulfate, protein contents, $\mathrm{pH}$

\section{PENDAHULUAN}

Di Indonesia banyak dibudidayakan tanaman nanas karena Indonesia merupakan salah satu negara yang beriklim tropis yang sesuai dengan syarat tumbuh dari tanaman nanas. Nanas merupakan tanaman buah berupa semak, dengan ujung daun dan tepi daun yang berduri dan memiliki tulang daun yang sejajar. Kemudian memiliki kulit yang berwarna hijau kekuning-kuningan, serta daging buah berwarna kuning (Hairi, 2010). Buah nanas yang sudah masak dapat dikonsumsi langsung sebagai buah segar dan yang dikonsumsi adalah bagian dagingnya saja, setelah dikupas kulitnya dan dibersihkan dari duri-durinya yang kemudian dicuci dan diberi garam, karena ada rasa getir dan cairannya yang kadangkala menusuk perut terutama bagi yang sakit lambung (maag) atau dalam bentuk buahbuahan kaleng. Sedangkan pada bagian batang, daun, kulit dan bonggolnya hanya dibuang begitu saja dan bahkan digunakan sebagai pakan ternak (Effendi dan Winarni, 2012). Buah nanas mengandung gizi cukup tinggi dan lengkap, seperti protein, lemak, karbohidrat, mineral, dengan kandungan air 90\% dan kaya akan kalium, kalsium, iodium, sulfur dan khlor. Selain itu nanas kaya dengan biotin, vitamin B12, vitamin E serta enzim bromelin (Kumaunang dan Kamu, 2011).

Enzim bromelin merupakan enzim yang dapat menghidrolisis ikatan peptida pada kandungan protein menjadi asam amino. Enzim bromelin memiliki sifat yang mirip dengan enzim proteolitik, yakni memiliki kemampuan untuk menghidrolisis protein lainnya, seperti enzim rennin (renat), papain, dan fisin (Christy, 2012). Enzim bromelin memiliki manfaat yang sangat banyak bagi kehidupan manusia yaitu dapat mendegradasi kolagen daging, sehingga dapat mengempukkan daging (Utami, 2010), kemudian pada pengolahan VCO yaitu enzim bromelin menghidrolisis protein menjadi senyawa-senyawa yang lebih sederhana pada santan (Edawati, 2005). Sedangkan pada bidang kesehatan enzim bromelin dapat mengurangi rasa sakit dan pembengkakan karena luka atau operasi, mengurangi radang sendi, menyembuhkan luka bakar, serta 
meningkatkan fungsi paru-paru pada penderita infeksi saluran pernapasan (Kumaunang dan Kamu, 2011). Selain itu enzim bromelin dapat melarutkan lendir yang sangat kental dalam sistem pencernaan, memecah lemak di usus sehingga membantu membersihkan usus dan saluran pencernaan, mengurangi tekanan darah tinggi, mengurangi kadar kolesterol darah (membersihkan darah) dan mencegah stroke. Mencuci timbunan protein dan parasit cacing pada dinding usus sehingga dapat dengan mudah dikeluarkan melalui feces. Menghambat pertumbuhan sel kanker dan merangsang serta meningkatkan sistem pertahanan tubuh (Indrawati, T. 1992).

Menurut penelitian terdahulu (Wuryanti, 2004) Enzim bromelin kasar hasil isolasi dari bonggol nanas mempunyai unit aktivitas 5,373 $\mathrm{U} / \mathrm{mL}$, kadar protein $10,299 \mathrm{mg} / \mathrm{mL}$, aktivitas spesifik 0,521 U/mg dan menurut (Wuryanti, 2006) berat molekul 33.500, titik isoelektrik : pH 9,55, pH optimum : 6-8, suhu optimum: $50^{\circ} \mathrm{C}$, aktivitas spesifik: $5-10 \mathrm{U} / \mathrm{mg}$ protein. Sedangkan pada kulit nanas memiliki kandungan enzim bromelin, dengan aktivitas optimum diperoleh pada temperatur $65 \mathrm{oC}$ sebesar 0,071 unit/menit dan pada $\mathrm{pH}$ 6,5 sebesar 0,101 unit/menit (Kumaunang dan Kamu, 2011, 4).

Menurut Gautam dkk (2010) enzim bromelin yang diisolasi dari buah dan batang nanas memiliki aktivitas yang berbeda. Aktivitas enzim bromelin dari batang lebih tinggi yakni 3,500 GDU/gram sedangkan enzim bromelin dari buah nanas hanya 1,500 GDU/gram. Berdasarkan beberapa hasil penelitian tersebut di atas maka diduga aktivitas enzim bromelin dari batang nanas juga memiliki aktivitas yang lebih tinggi di bandingkan bagian lain pada nanas. Dengan demikian penelitian ini dilakukan untuk mengetahui aktivitas optimum ekstrak kasar enzim bromelin yang diisolasi dari batang nanas.

\section{METODE}

Pembuatan Ekstrak Kasar Batang Nanas. Batang nanas yang digunakan adalah batang yang berasal dari buah nanas yang mangkal, ditandai dengan warna kulitnya hijau kekuningan. Batang nanas dicuci dengan akuades kemudian ditimbang sebanyak 750 gram. Selanjutnya dihomogenisasi dengan menggunakan $100 \mathrm{~mL}$ larutan buffer natrium asetat yang berfungsi untuk mengontrol $\mathrm{pH}$ $(6,5)$ agar selalu dalam keadaan asam dan disaring. Ekstrak kasar disentrifugasi selama 25 menit pada $3.500 \mathrm{rpm}$, dan disimpan pada suhu $4^{0} \mathrm{C}$.

Pengendapan dengan Ammonium Sulfat. Penambahan ammonium sulfat berfungsi untuk mempresipitasi ekstrak kasar enzim bromelin, dengan konsentrasi masingmasing $10 \%, 20 \%, 30 \%, 40 \%, 50 \%$ dan $60 \%$, sambil diaduk menggunakan pengaduk magnet atau di vorteks selama 45 menit, dan di inkubasi semalam di dalam kulkas. Selanjutnya, disentrifugasi pada $3500 \mathrm{rpm}$ selama 25 menit. Endapan yang dihasilkan dicuci dengan $10 \mathrm{~mL}$ buffer natrium asetat 0,1 $\mathrm{M}$ pada kisaran $\mathrm{pH} 6-6,5$ dan dilakukan sebanyak 3 kali ulangan.

Penentuan Kadar Protein Ekstrak Kasar Enzim Bromelin. Penentuan kadar protein dilakukan dengan menggunakan metode Bradford, yaitu untuk mengukur konsentrasi protein total secara kalorimetri dalam suatu larutan. Dalam uji Bradford melibatkan pewarna Coomassie Brilliant Blue (CBB) yang berikatan dengan protein dalam suatu larutan yang bersifat asam sehingga memberikan warna (kebiruan). Dan absorbansinya diukur pada $\lambda 595 \mu \mathrm{m}$. Kadar protein ditentukan dengan membandingkan absorbansi ekstrak kasar enzim bromelin dengan kurva standar gelatin. Pembuatan larutan standar gelatin yaitu dengan cara menimbang $0,01 \mathrm{~g}$ gelatin kemudian dilarutkan dengan $10 \mathrm{ml}$ akuades steril sehingga diperoleh larutan stok gelatin pada konsentrasi 1000 ppm. Larutan stok pada konsentrasi $1000 \mathrm{ppm}$ diencerkan dengan melarutkan $0,5 \mathrm{ml}$ larutan stok ditambahkan 4,5 $\mathrm{ml}$ akuades steril sehingga diperoleh larutan stok gelatin 100 ppm. Dari larutan stok tersebut dilakukan pengukuran terhadap standar protein terlarut dengan konsentrasi 10, 20, 30, 40, 50 dan 60 ppm. Kemudian dilakukan pengukuran terhadap standar protein dengan menambahkan $0,005 \mathrm{ml}$ seri larutan 
standar dengan 2,5 $\mathrm{ml}$ reagen Bradford dan larutan tersebut divortex serta di inkubasi pada suhu ruang selama 10-60 menit. Larutan ini bersifat asam sehingga memberikan warna biru, kemudian selanjutnya diukur absorbansinya pada $\lambda 595 \mathrm{~nm}$. Pengukuran absorbansi (protein terlarut) pada ekstrak batang nanas yaitu dengan cara $0,5 \mathrm{ml}$ seri ekstrak enzim kasar ditambahkan dengan 2,5 $\mathrm{ml}$ reagen Bradford, kemudian divortex lalu di inkubasi pada suhu ruang selama 10-60 menit. Absorbansi Larutan sampel protein selanjutnya diukur absorbansinya pada $\lambda 595$ $\mu \mathrm{m}$ (Bradford et al., 1976).

Penentuan Aktivitas Enzim Bromelin dalam hal ini yaitu Penentuan pH Optimum. Sebanyak $0,125 \mathrm{~mL}$ gelatin ditambahkan dengan $0,5 \mathrm{~mL}$ buffer asam fosfat $1 \mathrm{M}(\mathrm{pH} 6,5)$ dan 0,125 gram ekstrak kasar enzim bromelin, kemudian diinkubasi pada suhu $650 \mathrm{o}$ selama 10 menit pada berbagai nilai $\mathrm{pH}$ pada temperatur optimum yang diperoleh (Kumaunang dan Kamu, 2011). Variasi nilai $\mathrm{pH}$ yang digunakan adalah 4,$0 ; 5,0 ; 6,0 ; 7,0 ; 8,0$. Reaksi dihentikan dengan pemanasan pada air mendidih selama 10 menit dan di lakukan sebanyak 3 kali pengulangan serta absorbansinya diukur pada $\lambda 595 \mathrm{~nm}$.

Analisis Data. Penentuan kadar protein ditentukan dengan membandingkan absorbansi ekstrak enzim bromelin dengan persamaan linear kurva standar gelatin. Sedangkan aktivitas enzim bromelin dapat ditentukan dengan rumus di bawah ini:

Aktivitas Enzim $=$ Substrat Terhidrolisis $\mathrm{x}$

$\frac{1}{\text { BM Enzim }} \times \frac{\text { Volume Larutan }}{\text { Berat Enzim }}$

BM Enzim $=181.19 \mathrm{~g} / \mathrm{mol}($ Ishak, 2012, 66)

\section{HASIL}

\section{Pengukuran Kadar Protein Enzim} Bromelin pada Variasi Konsentrasi Ammonium Sulfat. Pengukuran kadar protein enzim bromelin dari ekstrak batang nanas yaitu dengan perlakuan batang nanas yang telah di saring dan ditambahkan larutan ammonium sulfat dengan variasi $10 \%, 20 \%, 30 \%, 40 \%$, $50 \%$ dan $60 \%$ kemudian diinkubasi agar enzim bromelin mengendap. Kadar protein yang diperoleh pada pengendapan ammonium sulfat ini dapat dilihat pada tabel berikut:

Tabel 1. Kadar Protein Enzim Bromelin dari Ekstrak Kasar Batang Nanas pada Variasi Amonium Sulfat

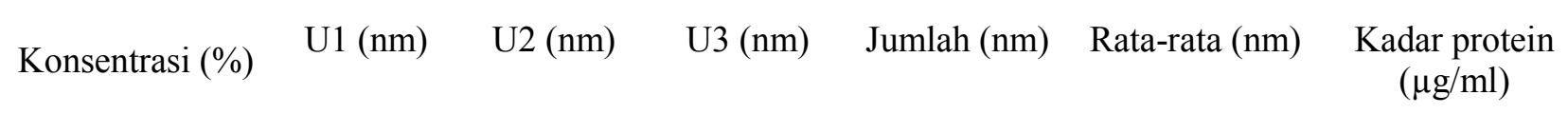

\begin{tabular}{ccccccc}
\hline 10 & 0,995 & 1 & 1,007 & 3,002 & 1,000666667 & 36,988 \\
\hline 20 & 0,996 & 1,009 & 1 & 3,005 & 1,001666667 & 37,023 \\
\hline 30 & 1,016 & 0,991 & 1,005 & 3,012 & 1,004 & 37,107 \\
\hline 40 & 0,995 & 1 & 1 & 2,995 & 0,998333333 & 36,904 \\
\hline 50 & 0,996 & 0,995 & 0,989 & 2,98 & 0,993333333 & 36,726 \\
\hline 60 & 1,016 & 0,993 & 1,06 & 3,069 & 1,023 & 37,785
\end{tabular}

Keterangan:

$\mathrm{U} 1=$ ulangan $1 . \mathrm{U} 2=$ ulangan $2 . \mathrm{U} 3=$ ulangan 3 


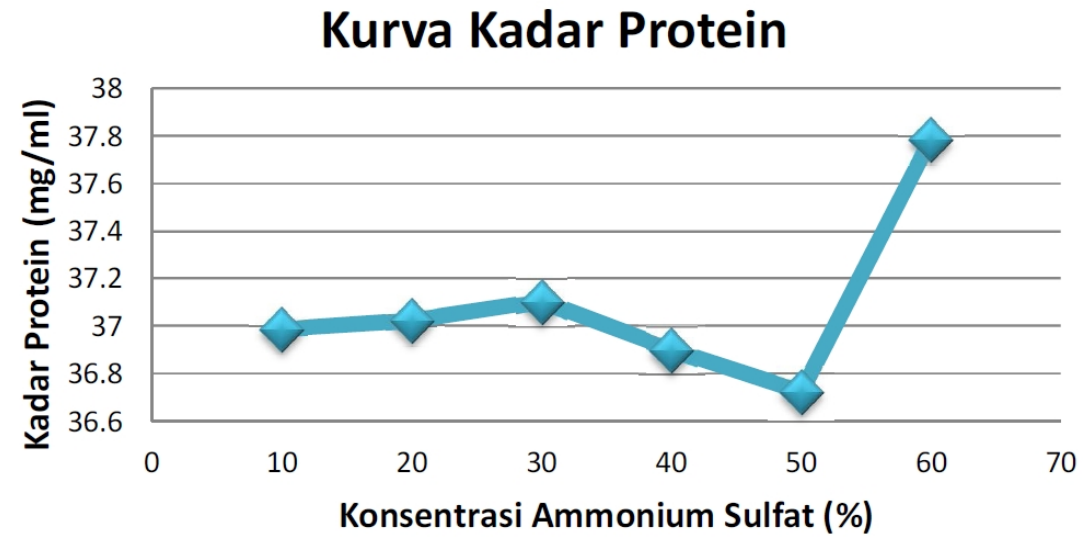

Gambar 1.Grafik Pengaruh Konsentrasi Ammonium Sulfat terhadap Pengendapan Protein Enzim Bromelin

\section{Hubungan Antara pH Inkubasi} Terhadap Aktivitas Ekstrak Kasar Enzim Bromelin Aktivitas enzim bromelin dari batang nanas diukur berdasarkan kemampuannya dalam menghidrolisis substrat gelatin. Pengukuran dilakukan secara spektrofotometri pada panjang gelombang 595 nm. Hasil yang diperoleh dapat dilihat pada tabel berikut:

Tabel 2. Aktivitas Enzim Bromelin pada Variasi $\mathrm{pH}$

\begin{tabular}{lllllll}
\hline $\mathrm{pH}$ & $\begin{array}{l}\mathrm{U} 1 \\
(\mathrm{~nm})\end{array}$ & $\begin{array}{l}\mathrm{U} 2 \\
(\mathrm{~nm})\end{array}$ & $\begin{array}{l}\mathrm{U} 3 \\
(\mathrm{~nm})\end{array}$ & $\begin{array}{l}\text { Rata-rata } \\
(\mathrm{nm})\end{array}$ & $\begin{array}{l}\text { Substrat } \\
\text { terhidrolisis } \\
(\mathrm{g} / \mathrm{ml})\end{array}$ & $\begin{array}{l}\text { Aktivitas enzim } \\
(\text { unit/g) }\end{array}$ \\
\hline 4 & 1 & 1,001 & 0,999 & 1 & 36,964 & 1,020 \\
\hline 5 & 1,007 & 0,996 & 0,998 & $10,003,333$ & 36,976 & 1,020 \\
\hline 6 & 1,004 & 1 & 1 & $10,013,333$ & 37,011 & 1,021 \\
\hline 7 & 1,003 & 1 & 0,999 & $10,006,667$ & 36,988 & 1,020 \\
\hline 8 & 1 & 0,999 & 0,999 & 0,9993333 & 36,940 & 1,019
\end{tabular}

\section{Keterangan:}

$\mathrm{U} 1=$ ulangan $1 . \mathrm{U} 2=$ ulangan $2 . \mathrm{U} 3=$ ulangan 3

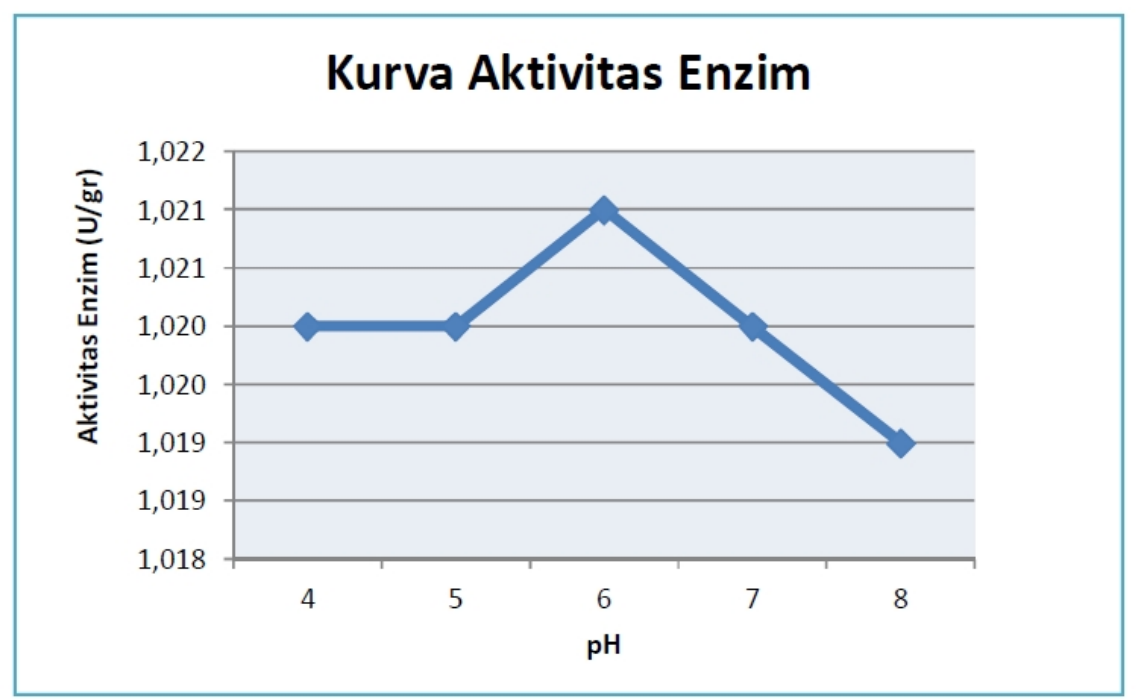

Gambar 2. Grafik Pengaruh Variasi pH terhadap Aktivitas Enzim 


\section{PEMBAHASAN}

Proses isolasi dilakukan untuk mendapatkan ekstrak kasar enzim bromelin. Pada penelitian ini enzim bromelin kasar diisolasi dari batang nanas (stem bromelin). Enzim bromelin tergolong dalam kelompok enzim protease sulfhidril yang dapat menghidrolisa protein menghasilkan asam amino sederhana yang larut dalam air. Sisi aktif enzim bromelin ini mengandung gugus sistein dan histidina yang penting untuk aktivitas enzim tersebut. Sehingga enzim ini secara khusus memotong ikatan peptida pada gugus karbonil seperti yang ditemukan dalam arginin atau asam amino aromatik yaitu fenilalanin atau tirosin (Gautam et al., 2010, 75). Enzim bromelin ini menghidrolisis ikatan peptida di bagian tengah rantai peptida, sehingga digolongkan endopeptidase. Apabila ekstrak kasar enzim bromelin telah diperoleh, maka protein dapat diuji secara kuantitatif dengan menggunakan spektrofotometer pada panjang gelombang $595 \mathrm{~nm}$. Digunakan panjang gelombang $595 \mathrm{~nm}$ karena pada penentuan panjang gelombang maksimum pada gelatin (coomassine) didapat Proses isolasi dilakukan untuk mendapatkan ekstrak kasar enzim bromelin.

Enzim bromelin tergolong dalam kelompok enzim protease sulfhidril yang dapat menghidrolisa protein menghasilkan asam amino sederhana yang larut dalam air. Sisi aktif enzim bromelin ini mengandung gugus sistein dan histidina yang penting untuk aktivitas enzim tersebut. Sehingga enzim ini secara khusus memotong ikatan peptida pada gugus karbonil seperti yang ditemukan dalam arginin atau asam amino aromatik yaitu fenilalanin atau tirosin (Gautam et al., 2010, 75). Enzim bromelin ini menghidrolisis ikatan peptida di bagian tengah rantai peptida, sehingga digolongkan endopeptidase. Apabila ekstrak kasar enzim bromelin telah diperoleh, maka protein dapat diuji secara kuantitatif dengan menggunakan spektrofotometer pada panjang gelombang $595 \mathrm{~nm}$. Digunakan panjang gelombang $595 \mathrm{~nm}$ karena pada penentuan panjang gelombang maksimum pada gelatin (coomassine) didapat bahwa panjang gelombang maksimumnya $595 \mathrm{~nm}$
(Azhari, A. 2010). Dari hasil pembacaan spektrofotometer tersebut diperoleh kurva standar gelatin dengan persamaan regresi $\mathrm{y}=$ $0,028 \mathrm{x}-0,035$. Gelatin digunakan sebagai larutan standar, karena gelatin mengandung banyak asam amino yang menjadi sisi pengenalan atau daerah pemotongan enzim bromelin yaitu di antaranya adalah: argininarginin dan lysin-tyrosin (Junianto, Kiki Haetami dan Maulina, 2006).

Pengukuran Kadar Protein Enzim Bromelin pada Variasi Amonium Sulfat 10$60 \%$. Penentuan kadar protein enzim bromelin dilakukan dengan menggunakan metode Bradford dan gelatin sebagai standar. Pada batang nanas memiliki jumlah protein tertinggi dibandingkan bagian yang lain pada tanaman nanas dan termasuk bagian bonggolnya (Gautam, 2010). Pengendapan protein dengan amonium sulfat dapat dilakukan pada konsentrasi $10-100 \%$, tetapi pada konsentrasi 60-100 \% pengendapan protein semakin berkurang dikarenakan larutan protein mengalami titik kejenuhan (Soares, et al. 2010). Oleh karena itu pada penelitian ini menggunakan konsentrasi 10$60 \%$. Berdasarkan tabel 4.1 yang menunjukkan bahwa kadar protein tertinggi diperoleh sebanyak $37,785 \mathrm{mg} / \mathrm{ml}$ pada konsentrasi $60 \%$ amonium sulfat. Sedangkan kadar protein terendah diperoleh pada konsentrasi $50 \%$ sebanyak 36,904 $\mathrm{mg} / \mathrm{ml}$. Hasil penelitian ini sesuai dengan hasil penelitian yang dilakukan oleh (Kumaunang dan Kamu, 2010) yaitu kadar protein tertinggi enzim bromelin pada penambahan amonium sulfat $60 \%$, dengan nilai sebanyak $0,039 \%$. Kadar protein tertinggi diperoleh pada konsentrasi amonium sulfat $60 \%$, karena pada konsentrasi ini kelarutan protein akan berkurang hingga minimum sehingga protein mengendap. Pengendapan ini terjadi karena proses persaingan antara garam dan protein untuk mengikat air. Grup ion pada permukaan protein menarik banyak molekul air dan berikatan dengan sangat kuat. Amonium sulfat yang ditambahkan ke dalam larutan protein akan menyebabkan tertariknya molekul air oleh ion garam. Hal tersebut disebabkan ion garam memiliki densitas muatan yang lebih 
besar dibandingkan protein. Kekuatan ionic garam pada konsentrasi tinggi semakin kuat sehingga garam dapat lebih mengikat molekul air. Menurunnya jumlah air yang terikat pada protein menyebabkan gaya tarik menarik antara molekul protein lebih kuat bila dibandingkan dengan gaya tarik menarik antara molekul protein dan air (mempertinggi interaksi hidrofobik), sehingga protein akan mengendap dari larutan atau berikatan dengan kolom hidrofobik (Wirahadikusumah, 2001).

Hubungan Antara pH Inkubasi Terhadap Aktivitas Ekstrak Kasar Enzim Bromelin. Perlakuan $\mathrm{pH}$ memiliki pengaruh terhadap aktivitas enzim bromelin yang diperoleh. Hal ini terlihat pada Gambar 4.3 yang menunjukkan bahwa kondisi optimum enzim bromelin diperoleh pada $\mathrm{pH}$ 6,0 dengan aktivitas 1,021 U/gr dengan substrat terhidrolisis sebesar $37,011 \mathrm{gr} / \mathrm{ml}$ yang selanjutnya mengalami penurunan pada $\mathrm{pH} 7$ dan $\mathrm{pH}$ 8. Hal ini terjadi karena adanya pengaruh oleh konsentrasi ion $\mathrm{H}+$, atau dengan kata lain, derajat keasaman dari pelarut yang mengelilingi protein enzim bromelin. Pada kondisi $\mathrm{pH}$ yang tepat, terjadi perubahan gugus ion pada sisi aktif enzim sehingga konformasi enzim lebih efektif dalam mengikat dan mengubah substrat menjadi produk. $\mathrm{pH}$ optimum merupakan $\mathrm{pH}$ saat gugus pemberi dan penerima proton (ion positif) yang berperan penting pada sisi katalitik enzim atau pada sisi pengikat substrat berada dalam tingkat ionisasi yang diinginkan, sehingga substrat lebih mudah berinteraksi dengan sisi katalitik enzim (Nielsen et al., (1999).

Aktivitas enzim bromelin dari batang nanas optimum pada $\mathrm{pH} 6$, sedangkan isolat enzim bromelin dari bonggol nanas berdasarkan hasil penelitian (Dian hardiana, 2013) memiliki aktivitas optimum pada pH 7. Dengan demikian diketahui bahwa enzim bromelin dari nanas tetapi dari organ yang berbeda memiliki $\mathrm{pH}$ optimum yang berbeda pula. Enzim tertentu mempunyai kisaran $\mathrm{pH}$ optimum yang sangat sempit di sekitar $\mathrm{pH}$ optimum enzim yang stabilitasnya tinggi. Dalam hal ini enzim yang sama seringkali $\mathrm{pH}$ optimumnya berbeda, karena tergantung dari sumber enzim tersebut.
Hasil penelitian ini sesuai dengan hasil penelitian sebelumnya yang dilakukan oleh (Wuryanti, 2006) dimana $\mathrm{pH}$ optimum dari enzim bromelin yaitu berkisar antara $\mathrm{pH}$ 6-8. Aktivitas bromelin optimumnya pada $\mathrm{pH} 6$ sampai 7 dimana enzim akan mempunyai konformasi yang mantap dan aktivitas maksimal. Menurunnya aktivitas enzim pada pH 7 dan $\mathrm{pH} 8$ pada penelitian ini sama dengan hasil penelitian yang dilakukan oleh (Kumaunang dan Kamu, 2011). Penurunan aktivitas enzim dari $\mathrm{pH}$ 7,0 sampai $\mathrm{pH} 8,0$ terjadi karena lingkungan di sekitar sisi aktif enzim mengalami kekurangan jumlah proton. Karena pada pH 7 dan 8 suasana lingkungan disekitar sisi aktif enzim bromelin berada dalam suasana basa, sehingga ion $\mathrm{H}+$ berkurang. Dimana proton itu sendiri merupakan ion positif yang terdapat pada larutan disekitar enzim bromelin apabila dalam keadaan asam. Enzim bromelin bersifat hidrolase, yaitu enzim yang bekerja dengan adanya air. Protein mengandung asam amino bersifat hidrofilik, yaitu protein yang residu asam aminonya bersifat menyukai air. Hal ini disebabkan dengan adanya gugus hidrogen pada peptida yang merupakan molekul organik polar, sehingga akan membentuk air dengan adanya gugus $\mathrm{OH}$.

\section{KESIMPULAN}

Kadar protein tertinggi hasil ekstraksi dari batang nanas berdasarkan variasi ammonium sulfat yaitu pada konsentrasi $60 \%$ dengan kadar protein sebesar 37,785 mg/ml. Aktivitas optimum enzim bromelin yang di ekstrak dari batang nanas yaitu pada $\mathrm{pH} 6$ yang merupakan aktivitas tertinggi dengan aktivitas 1,021 U/gr.

Sebaiknya untuk menguji aktivitas enzim bromelin yang diekstrak dari batang nanas menggunakan parameter yang lebih dari satu, agar dapat membandingkan hasil aktivitas dari tiap parameter tersebut. Sebaiknya enzim bromelin yang diperoleh dari batang nanas dilanjutkan dengan penguujian bioremediasi pada limbah protein, seperti limbah dari pabrik tepung. Sebaiknya melakukan penelitian pendahuluan agar mengurangi kesalahan pada saat penelitian atau untuk mendapatkan hasil yang lebih akurat. 


\section{DAFTAR PUSTAKA}

Azhari A. 2010. Penentuan Kadar Protein Dengan Metode Bradford. Bogor: Institut Pertanian Bogor.

Bradford MM. 1976. A rapid and sensitive method for the quantitation of microgram quantities of protein utilizing the principle of protein-dye binding. Anal Biochem. vol 1(2):1.

Charlena AG, dan Rifani. 2005. Aktivitas Bromelain Pada Limbah Padat Pengalengan Nenas Dan Pengaruh Semipurifikasi. Banten: Prosiding Seminar Nasional Teknologi Pengelolaan Limbah IX. Pusat Teknologi Limbah Radioaktif-BATAN Fakultas Teknik Universitas Sultan Ageng Tirtayasa. ISSN 1410-6086.

Christy MI. 2012. Pengaruh Proses Pengeringan dan Imobilisasi Terhadap Aktivitas dan Kestabilan Enzim Bromelain dari Buah Nenas (Ananas comosus (L) Merr). Makassar: Jurusan Teknologi Pertanian Fakultas Pertanian Universitas Hasanuddin.

Edawati L. 2011. Aplikasi Penggunaan Enzim Papain Dan Bromelin Terhadap Perolehan Vco. Cet. 1. Yogyakarta: UPN Press.

Effendi AM, Winarni, Sumarni W. 2012. Optimalisasi Penggunaan Enzim Bromelin dari Sari Bonggol Nanas Dalam Pembutan Minyak Kelapa. Indonesia Journal of Chemical Science. vol 1 (1):1.

Gautam SS, Mishra S, Dash V, Amit K and Rath G. 2010. Cooperative Study or Extraction, Purification and Estimation of Bromelain from Stem and Fruit of Pineapple Plant. Thai J. Pharm., Sci. vol $1(1): 2$.

Hadianti S, dan Sukmadjaja D. 2002. Keragaman Pola Pita Beberapa Aksesi Nenas Berdasarkan Analisis Isozim. Jurnal Bioteknologi Pertanian. vol 7 (2):62-70.

Hairi M. 2010. Pengaruh Umur Buah Nanas Dan Konsentrasi Ekstrak Kasar Enzim
Bromelin Pada Pembuatan Virgin Coconut Oil Dari Buah Kelapa Typical (Cocos nucifera L.). Malang: Jurusan Kimia Fakultas Sains Dan Teknologi Universitas Islam Negeri Maulana Malik Ibrahim Malang.

Indrawati T. 1992. Pembuatan Kecap Keong Sawah dengan Menggunkan Enzim Bromelin. Semarang: Balai Pustaka dan Media Wiyata.

Junianto KH, dan Maulina I. 2006. Produksi Gelatin dari Tulang Ikan dan Pemanfaatannya Sebagai Bahan Dasar Pembuatan Cangkang Kapsul. Bandung: Universitas Padjadjaran.

Kumaunang M, dan Kamu V. Aktivitas Enzim Bromelin Dari Ekstrak Kulit Nenas (Anenas comosus). Jurnal Ilmiah Sains. vol 11 (2): 1.

Soares P. 2010. Studies on Bromelain Precipitation by Ethanol, Poly (Ethylene Glycol) and Ammonium Sulphate. Brazil: Universidade de São Paulo. http://www.method-of-bromelaiextraction.pdf. Diakses 19 Mei 2013.

Utami DP, Pudjomartatmo, dan Nuhriawangsa AMP. 2011. Manfaat Bromelin dari Ekstrak Buah Nanas (Ananas comosus L. Merr) dan Waktu Pemasakan untuk Meningkatkan Kualitas Daging Itik Afkir. Sains Peternakan. vol 9 (2): 82-87. ISSN 1693-8828.

Wirahadikusumah M. 1977. Biokimia Protein, Enzim dan Asam Nukleat. Bandung: Institut Teknologi Bandung.

Wuryanti. 2006. Amobilisasi Enzim Bromelin Dari Bonggol Nanas Dengan Bahan Pendukung (Support) Karagenan Dari Rumput Laut (Euchema Cottonii). JSKA. vol IX (3): 1.

Wuryanti. 2004. Isolasi dan Penentuan Aktivitas Spesifik Enzim Bromelin Dari Buah Nanas (Ananas comosus L.). JKSA. vol. VII (3):1. 